\title{
'Epidemiological' treatment in non-venereal and in treponemal diseases
}

\author{
R. R. WILLCOX \\ St. Mary's Hospital, London, and King Edward VII Hospital, Windsor
}

'Epidemiological' treatment, sometimes referred to as 'treatment before diagnosis', has well-recognized indications in many fields of medicine and yet when applied to the venereal diseases may be regarded as an emotionally controversial issue amongst some venereologists, comparable with those of suspected racial or religious discrimination, abortion, contraception, and increased taxation in the population at large.

The stated objections to epidemiological treatment may be listed as follows:

May breed anxiety in the patients

Risk of penicillin reaction

Medico-legal difficulties

May foster penicillin resistance (e.g. of gonococci)

Lowers standards of physicians

'Second rate treatment'

'Undesirable expedient'

More than 18 years ago the author (Willcox, 1954) was engaged in debate with the President Emeritus of the International Union against the Venereal Diseases and Treponematoses (IUVDT) on this subject (King, 1954) before the Medical Society for the Study of Venereal Diseases in London. This debate has since been partially revived in the correspondence columns of the medical press (Willcox, 1968; King, 1968).

At the conclusion of the debate in 1953, which the writer lost, he stated the belief that not so much separated the opposing views as at first sight appeared. Indeed, if the word 'indiscriminate' were to be placed before 'epidemiological' there would then and now be virtually complete agreement between the two parties.

The object of this paper is not to engender further heat and to continue controversy but once again to advance the thesis that discriminate epidemiological treatment has a definite place in venereology as first-rate treatment and as a most desirable expedient, and to try to define the circumstances in which the procedure is most valuable.

\section{Definition}

It is important that the terms used should be clearly understood. There are difficulties in terminology in different languages and considerable confusion results. The terminology used in this paper is set out in Table I.

TABLE I Definitions of terminology of treatment before diagnosis

\begin{tabular}{lll}
\hline Term & Nature of risk & Relation to exposure \\
\cline { 1 - 2 } $\begin{array}{l}\text { Prophylactic } \\
\text { 'preventive' } \\
\text { treatment }\end{array}$ & Unknown & Before \\
\hline $\begin{array}{l}\text { Epidemiological } \\
\text { 'abortive' } \\
\text { treatment }\end{array}$ & Unknown & After \\
\hline
\end{tabular}

The term 'prophylactic' or 'preventive' is used when it is not known whether a person has actually been exposed to the disease being prevented and it may be applied before or after exposure. The term 'epidemiological' or 'abortive' is reserved for treatment given after exposure, when it is known for certain that contact with a defined disease has occurred. The difference between post-exposure prophylactic treatment and post-exposure epidemiological treatment is that of the degree of risk of infection which has been incurred.

Factors involved in treatment before diagnosis The most important factors to be considered before such treatment is used are as follows:

Risk of infection

Seriousness of disease

Effectiveness of procedure

Incidence of side-effects

Likelihood of spread if procedure is not used

(Modified from O'Grady, 1972) 
To this must be added, in respect of epidemiological treatment, the possibility of making a rapid, accurate, and definitive diagnosis.

The likelihood of spread if the procedure is not used is related not only to the other factors listed but also to the facilities and opportunities for observation. These factors are inter-related. Obviously, if the risk of developing the disease is 100 per cent., the procedure is 100 per cent. effective, and there is a zero incidence of side-effects, a physician could be considered negligent not to adopt the procedure irrespective of the other considerations.

\section{Use of prophylactic and epidemiological treat- ment in non-venereal conditions}

PROPHYLACTIC (PREVENTIVE) TREATMENT

Some common uses of prophylactic treatment in non-venereal conditions are shown in Table II.

TABLE II Use of prophylactic treatment in nonvenereal conditions

\begin{tabular}{|c|c|c|}
\hline Relation to exposure & Organism & Disease \\
\hline \multirow[t]{3}{*}{ Pre-exposure } & Plasmodia & Malaria \\
\hline & Streptococcus & $\begin{array}{l}\text { Before dental extraction in } \\
\text { rheumatic and congenital } \\
\text { heart disease } \\
\text { Before cardiac surgery in } \\
\text { rheumatic fever to prevent } \\
\text { effects of throat infections } \\
\text { (continuous) }\end{array}$ \\
\hline & $\begin{array}{l}\text { Clostridia } \\
\text { Various }\end{array}$ & $\begin{array}{l}\text { Before mid-thigh amputation } \\
\text { 'Honeymoon' cystitis }\end{array}$ \\
\hline Post-exposure & Various & $\begin{array}{l}\text { Upper respiratory infections } \\
\text { in chronic bronchitics and } \\
\text { asthmatics }\end{array}$ \\
\hline
\end{tabular}

Most of these procedures are used against serious and life-threatening disease with a variable and sometimes unknown risk. The vast majority of physicians, including opponents of chemoprophylaxis against venereal diseases, who visit tropical lands consider it highly desirable to avail themselves of such protection against malaria even if the risks of contracting the disease are only slight in the areas visited, and they certainly recommend this course of action to their patients.

\section{EPIDEMIOLOGICAL (ABORTIVE) TREATMENT}

\section{General indications}

Possible indications for epidemiological treatment in non-venereal conditions are shown in Table III.

The procedure is widely used in casualty and gynaecological departments on the indications listed,
TABLE II I Use of epidemiological treatment in non-venereal conditions

\begin{tabular}{|c|c|c|}
\hline Exposure & Organism & Disease \\
\hline \multirow[t]{3}{*}{ Post-exposure } & Variola virus & Smallpox \\
\hline & $\begin{array}{l}\text { Clostridia, } \\
\text { Streptococci, } \\
\text { and others }\end{array}$ & $\begin{array}{l}\text { Lacerated wounds } \\
\text { Prolonged rupture of } \\
\text { membranes } \\
\text { Possible septic abortion }\end{array}$ \\
\hline & $\begin{array}{l}T . \text { carateum } \\
T . \text { pertenue } \\
T . \text { pallidum }\end{array}$ & $\begin{array}{l}\text { Non-venereal } \\
\text { treponematoses }\end{array}$ \\
\hline
\end{tabular}

has undergone trials in India and South America in the prevention of smallpox (Bauer, 1967), and has been the mainstay in the successful WHO-assisted mass campaigns against the endemic treponematoses (Guthe and Idsøe, 1968).

TABLE IV Results of epidemiological treatment of smallpox

\begin{tabular}{|c|c|c|c|}
\hline \multirow[b]{2}{*}{ Treatment } & \multirow{2}{*}{$\begin{array}{l}\text { No. of } \\
\text { contacts }\end{array}$} & \multicolumn{2}{|c|}{ Developed smallpox } \\
\hline & & No. & Per cent. \\
\hline $\begin{array}{l}\text { Untreated } \\
\text { Given methisazone }\end{array}$ & $\begin{array}{l}2,815 \\
2,610\end{array}$ & $\begin{array}{r}116 \\
18\end{array}$ & $\begin{array}{l}4 \cdot 1 \\
0 \cdot 7\end{array}$ \\
\hline
\end{tabular}

From data of Bauer (1967) in Madras, India.

Use against smallpox

This is an interesting example; epidemiological treatment with methisazone has been advocated in addition to vaccination because of the seriousness of the disease and the likelihood of spread if the procedure is not used, although the risk of contracting the disease in a partially vaccinated population is small, the procedure is not completely effective, and the incidence and severity of side-effects (which should they prove severe would reduce its value) are not yet fully known (Table IV). In this instance, the seriousness of the disease in relation to its immediate mortality rate $(19.5$ per cent in the recent outbreak in Yugoslavia-WHO, 1972a) can override all other considerations.

Table IV illustrates the point that if a safe procedure were available it could in certain circumstances be desirable even if the risk were less than one in twenty.

Use of prophylactic and epidemiological treatment against the treponemal diseases

THE ENDEMIC TREPONEMATOSES

It was emphatically shown in the WHO-assisted mass campaign against endemic syphilis in Bosnia that contacts of clinical cases had to be treated if the campaign was to be successful (Grin, 1953). This is 
illustrated by data from one of the villages (Fig. 1). Unless possibly infectious latent cases and those at the incubation stage are treated, mass campaigns will be either unsuccessful or excessively slow in taking effect.

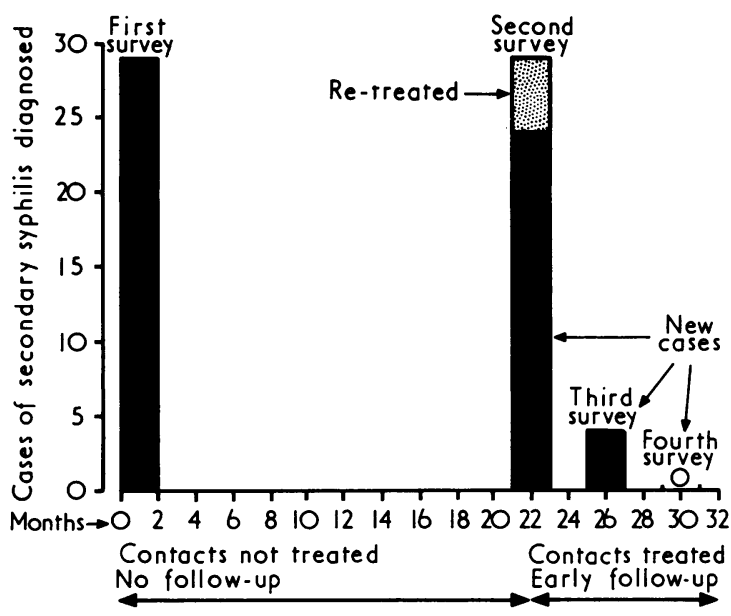

FIG. 1 Village in Bosnia. Effect of treating contacts in a mass campaign against endemic syphilis

A recommendation concerning the endemic treponematoses was made at that time by the WHO Expert Committee on Venereal Diseases and Treponematoses, the Report of which was forwarded to Member Governments by the Executive Board of WHO (WHO, 1953). This document stated that 'where treponemal diseases constitute a major public health problem, contacts without overt signs of disease receive preventive ('abortive') treatment with PAM'.

Shortly afterwards guidelines were suggested by WHO as to what sort of mass treatment should be used depending on prevalence (Table V).

TABLE V WHO mass treatment policies (see WHO, 1960)

\begin{tabular}{|c|c|c|}
\hline $\begin{array}{l}\text { Clinical prevalence } \\
\text { of yaws (per cent.) }\end{array}$ & $\begin{array}{l}\text { Type of mass } \\
\text { treatment }\end{array}$ & Persons treated \\
\hline $\begin{array}{l}\text { Over } 10 \\
5-10\end{array}$ & $\begin{array}{l}\text { Totala }^{\mathbf{a}} \\
\text { Juvenile }\end{array}$ & $\begin{array}{l}\text { All population } \\
\text { Cases plus all } \\
\text { children }\end{array}$ \\
\hline Under 5 & Selective & $\begin{array}{l}\text { Cases plus all } \\
\text { household and } \\
\text { obvious contacts }\end{array}$ \\
\hline
\end{tabular}

a Recommended for endemic syphilis when clinical prevalence exceeds 3 per cent.

These policies recommending epidemiological treatment, and for short periods prophylactic treatment also, which is inherent in the procedure, were endorsed by the Expert Committee on Venereal Infections and Treponematoses meeting in Geneva in 1959 under the Chairmanship of Prof. G. A. Canaperia, now President of the IUVDT. By this time the eradication of endemic syphilis in Bosnia had been achieved (WHO, 1960).

The numbers of persons who have been treated in the WHO-assisted campaigns run into many millions (WHO, 1972b):

Examined at initial treatment surveys

Examined at all surveys and re-surveys

$154,537,000$

$368,306,900$

Cases, contacts, and latent cases treated

$47,294,500$

In the circumstances existing in areas with endemic treponematoses, there may be high risks of infection but no possibilities for diagnosis other than clinical; the treatment is effective, there are negligible sideeffects (penicillin reactions being unlikely in unsophisticated peoples apart from possible localization of poliomyelitis-Guthe, Idsøe, and Willcox, 1958), there are no opportunities for subsequent observation, and there is considerable likelihood of spread if the procedure is not used.

Although yaws has not been completely eradicated in any major area, its prevalence has been reduced to small proportions. The success of the yaws campaigns has been paradoxically indicated in some areas by a biological side-effect, namely its replacement by venereal syphilis, e.g. in Tahiti (Van der Sluis, 1969), in New Guinea (Rhodes and Anderson, 1970), and elsewhere (Guthe and Idsøe, 1968). The writer has recently had the opportunity of observing the situation in New Guinea.

\section{VENEREAL ACQUIRED SYPHILIS}

Prophylactic antibiotic treatment against venereal syphilis when exposure to the disease is not definitely known to have occurred and the risk of infection is consequently very small, is very seldom given and has little if any approval by venereologists.

Mass campaigns using total mass treatment in areas of high prevalence have also not been applied against venereal syphilis to any significant extent. The reason has usually been that, with the existing promiscuity patterns within the area concernedwhich are likely to remain unaltered-and the inevitable rapid re-introduction of the disease from outside, any gains which are achieved are likely to be only temporary. They may occasionally be undertaken on a small scale amongst captive groups (e.g. the harem of an infected sheikh).

Nevertheless selective mass treatment (i.e. clinical cases and their sexual contacts) is indicated in underdeveloped countries with few facilities when a high prevalence of syphilis is found by survey or otherwise. This selective procedure is also widely used either 
routinely, as in the United States Public Health Service and by individual physicians (including the author) in many countries, or in selected cases (e.g. in late pregnancy, for those about to travel, and those considered likely to default). Its users employ clinical and serological examination in the first instance and, if treatment is offered but not imposed on the patient after the advantages and disadvantages have been explained, the patient nearly always accepts.

In the United States the procedure was first recommended in 1962, and has since gradually obtained acceptance. In the Fiscal Year 1970 it was employed on over 13,000 clinically and serologically negative contacts of the 15,425 cases of primary and secondary syphilis reported in that year (see Table VI), and it is estimated that between 1,500 and 3,000 cases of infectious syphilis were prevented (Brown, 1971).

TABLE VI Epidemiological treatment of clinically and serologically negative contacts of infectious syphilis in the U.S.A., 1970

\begin{tabular}{lll}
\hline $\begin{array}{l}\text { Time since exposure } \\
\text { (days) }\end{array}$ & No. examined & Per cent. treated \\
\hline Less than 30 & 7,845 & \\
\cline { 2 - 2 } $30-59$ & 5,606 & 87 \\
$60-89$ & 3,773 & 76 \\
\hline
\end{tabular}

Not all physicians, however, approve of this procedure (e.g. King and Nicol, 1969) for the reasons stated above, although its necessity is conceded in special cases, e.g. in late pregnancy.

It is noted that most but not all of the members of the recent International Travelling Seminar to the U.S.A., were to a greater or lesser extent opposed to the procedure in principle, but concluded that in the existing circumstances and with the present facilities, the measure was nevertheless necessary (WHO, 1972c). Also, although most of those who attended the meeting of the WHO Study Group on the Intercountry Spread of Venereal Disease in Copenhagen in December, 1971, indicated that they were strongly in favour of the preventive treatment of contacts of patients with proven disease, particularly in certain groups, it was realized that some held contrary opinions and that, particularly in small countries where good follow-up could be ensured, this method was still preferred by practising physicians. All of the Group, however, recognized the value of preventive treatment where itinerants and others who were unlikely to return for follow-up examination were concerned (WHO, 1972d).
Epidemiological profile

A profile regarding the epidemiological treatment of venereal syphilis is shown in Table VII.

TABLE VII Profile of epidemiological treatment of venereal syphilis

\begin{tabular}{|c|c|c|}
\hline Factors & Assessment & Reported figures \\
\hline Risk of infection & Medium & 9 to 30 per cent. a b c \\
\hline Seriousness of disease & Very serious & $\begin{array}{l}28 \text { per cent. late } \\
\text { lesions } \\
\begin{array}{l}\text { Death in } 10.8 \text { per } \\
\text { cent. }^{d}\end{array}\end{array}$ \\
\hline Difficulties in diagnosis & Delayed & $\begin{array}{l}9 \text { to } 90 \text { dayse, } 4 \text { to } 6 \\
\text { weeks using reagin } \\
\text { tests }\end{array}$ \\
\hline $\begin{array}{l}\text { Effectiveness of } \\
\text { treatment }\end{array}$ & Very effective & 100 per cent. $^{\mathrm{a} b}$ \\
\hline Side-effects & Few, if any & 0.7 per cent. ${ }^{\mathrm{g}} \mathrm{h}$ \\
\hline $\begin{array}{l}\text { Likelihood of spread } \\
\text { if procedure not used }\end{array}$ & $\begin{array}{l}\text { Depends on } \\
\text { promiscuity and } \\
\text { facilities for } \\
\text { observation } \\
\text { 'Ping-pong' infection } \\
\text { likely in regular } \\
\text { consorts }\end{array}$ & $\begin{array}{l}0 \text { to } 100 \text { per cent. } \\
(62 \cdot 1 \text { per cent. in } \\
\text { regular consorts })^{1}\end{array}$ \\
\hline $\begin{array}{l}\text { Facilities for } \\
\text { observation }\end{array}$ & Variable & $\begin{array}{l}\text { Default rates up to } \\
87 \text { per cent. (see } \\
\text { later Tables) }\end{array}$ \\
\hline
\end{tabular}

${ }^{\mathrm{a} M o o r e, ~ P r i c e, ~ K n o x, ~ a n d ~ E l g i n ~(1963), ~ b S c h r o e t e r, ~ T u r n e r, ~ L u c a s, ~}$ and Brown (1971), cASHA (1968): see Guthe, and Willcox (1971), ${ }^{d}$ Gjestland (1955), eWillcox (1964), 'USPHS (1968), 'BRudolph (1971), hWilkinson (1972), 'Alexander and Schoch (1949).

\section{Risk of infection}

The risk of infection amongst contacts of infectious syphilis is medium and has been assessed in two United States Public Health Service Studies (Moore and others, 1963; Schroeter and others, 1971). If all contacts within 90 days are considered the cumulative risk has been estimated at 10.9 per cent. (Table VIII).

TABLE VIII Placebo treatment of early syphilis contacts within 90 days of exposure

\begin{tabular}{|c|c|c|c|c|}
\hline \multirow{2}{*}{ Treated } & \multirow{2}{*}{$\begin{array}{c}\text { Observed } \\
3 \text { months } \\
\text { later } \\
.\end{array}$} & \multicolumn{2}{|c|}{ Developed syphilis } & \multirow{2}{*}{$\begin{array}{l}\text { Cumulative } \\
\text { percentage }\end{array}$} \\
\hline & & No. & Per cent. & \\
\hline 393 & 375 & 38 & $10 \cdot 1$ & 10.9 \\
\hline
\end{tabular}

From data of Moore and others (1963); Schroeter and others (1971).

In an outbreak of infectious syphilis in West Virginia, U.S.A. (Fig. 2), investigation of the chain of infection initiated by a teenager with secondary syphilis which ultimately involved 146 contacts, fifteen cases of syphilis (10.3 per cent.)-including 


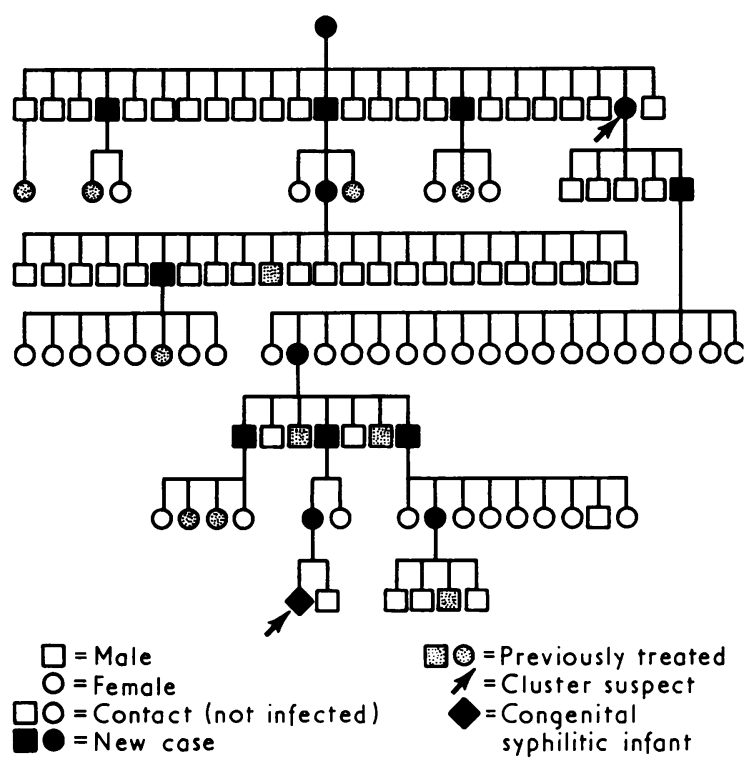

FIG. 2 Outbreak of infectious syphilis in West Virginia, U.S.A.

one newborn with congenital syphilis-were discovered (ASHA, 1968-see Guthe and Willcox, 1971). Had it been possible to give this girl epidemiological treatment as a contact in the first place, these infections could all have been prevented, as well as a great deal of epidemiological work.

The risk of infection amongst contacts is at least doubled if only those exposed in the previous 30 days are taken (Table IX).

TABLE IX Placebo treatment of early syphilis contacts less than 30 days since exposure

\begin{tabular}{|c|c|c|c|c|c|c|}
\hline \multirow[b]{2}{*}{ Authors } & \multirow[b]{2}{*}{ Date } & \multirow[b]{2}{*}{$\begin{array}{l}\text { No. } \\
\text { treated }\end{array}$} & \multirow[b]{2}{*}{$\begin{array}{l}\text { Observed } \\
\text { for } 3 \\
\text { months }\end{array}$} & \multicolumn{3}{|c|}{ Developed syphilis } \\
\hline & & & & No. & $\begin{array}{l}\text { Per } \\
\text { cent. }\end{array}$ & $\begin{array}{l}\text { Cumula- } \\
\text { tive per- } \\
\text { centage }\end{array}$ \\
\hline $\begin{array}{l}\text { Moore } \\
\text { and others }\end{array}$ & (1963) & 79 & 70 & 12 & $17 \cdot 1$ & $15 \cdot 9$ \\
\hline $\begin{array}{l}\text { Schroeter } \\
\text { and others }\end{array}$ & (1971) & 61 & 57 & 16 & $28 \cdot 1$ & $30 \cdot 3$ \\
\hline Total & & 140 & 127 & 28 & $22 \cdot 0$ & - \\
\hline
\end{tabular}

When regular consorts alone have been considered, much higher rates of infection have been reported, e.g. 60 to $66 \cdot 3$ per cent. (Marcussen, 1953) and $62 \cdot 1$ per cent. (Alexander and Schoch, 1949).

In respect of contacts 2 to 3 months previously however, the risk is low (Table X).
TABLE X Placebo treatment of early syphilis contacts 2 to 3 months since exposure

\begin{tabular}{llll}
\hline Treated & $\begin{array}{l}\text { Observed } \\
\text { for } \\
3 \text { months }\end{array}$ & & \multicolumn{2}{l}{ Developed syphilis } \\
\cline { 4 - 5 } & 248 & $\frac{\text { No. }}{10}$ & $\frac{\text { Per cent. }}{4 \cdot 0}$
\end{tabular}

From data of Moore and others (1963); Schroeter and others (1971).

\section{Seriousness of disease}

No one disputes the seriousness of venereal syphilis, although only a few patients suffer the late complications. In the Oslo Study of Untreated Syphilis (Gjestland, 1955), it was shown that approximately one in four untreated patients developed clinical secondary relapse, 15.8 per cent. benign late syphilis, 6.5 per cent. clinical neurosyphilis, and 10.4 cardiovascular syphilis. Altogether 28 per cent. developed some kind of late lesion and syphilis was the primary cause of death in 10.8 per cent.

\section{Difficulties in diagnosis}

These originate from the long incubation period, the possible absence of the primary lesion, or its concealment on the cervix in the female or within the anus of the male homosexual. Using reagin tests, 4 to 6 weeks usually elapse after exposure before serological tests become positive, and this is after the contagious, sometimes hidden, primary lesion has arisen (Willcox, 1964; USPHS, 1968). Earlier positivity is detectable by the FTA-ABS test (Niel and Fribourg-Blanc, 1965; Király, 1971), which is positive in most but not all cases by the time lesions are encountered by the physician (Garner, 1968). However, this test is not everywhere available as a routine procedure and, when it is, some time is required to obtain the result. Furthermore, the test will not detect the disease in the early incubation period in traced contacts who, if infected and untreated, will later become infectious and may be lost to observation.

Research has been aimed at finding an 'early warning' test for syphilis (Norins, 1968) and the necessity for epidemiological treatment would be much reduced if an effective test could be found to detect the disease soon after exposure, although it would still be necessary for persons unlikely to return to the clinic to learn the results of the tests, in areas with no follow-up facilities, and in places where the test was not available.

\section{Effectiveness of treatment}

Published data have indicated the complete ability of properly administered epidemiological treatment to prevent venereal syphilis (Table XI, overleaf). 
TABLE XI Effectiveness of epidemiological treatment with penicillin given to contacts less than one month after exposure

\begin{tabular}{|c|c|c|c|c|c|}
\hline \multirow[b]{2}{*}{ Penicillin } & \multirow{2}{*}{$\begin{array}{l}\text { Dose } \\
\text { (mega } \\
\text { units) }\end{array}$} & \multirow{2}{*}{$\begin{array}{l}\text { No. } \\
\text { treated }\end{array}$} & \multirow{2}{*}{$\begin{array}{l}\text { No. } \\
\text { followed } \\
\text { for } \\
3 \text { months }\end{array}$} & \multicolumn{2}{|c|}{ Developed syphilis } \\
\hline & & & & No. & Per cent. \\
\hline Benzathine & $\begin{array}{l}2 \cdot 4 \\
0 \cdot 6\end{array}$ & $\begin{array}{r}197 \\
70\end{array}$ & $\begin{array}{r}175 \\
60\end{array}$ & $\begin{array}{l}\text { nil } \\
\text { nil }\end{array}$ & $\begin{array}{l}\text { nil } \\
\text { nil }\end{array}$ \\
\hline PAM & $2 \cdot 4-3 \cdot 0$ & 24 & 19 & nil & nil \\
\hline $\begin{array}{l}\text { Aqueous } \\
\text { procaine }\end{array}$ & $\begin{array}{l}2 \cdot 4 \\
4 \cdot 8\end{array}$ & $\begin{array}{l}55 \\
72\end{array}$ & $\begin{array}{l}51 \\
66\end{array}$ & $\begin{array}{l}\text { nil } \\
\text { nil }\end{array}$ & $\begin{array}{l}\text { nil } \\
\text { nil }\end{array}$ \\
\hline Total & & 418 & 371 & nil & nil \\
\hline $\begin{array}{l}\text { Aqueous } \\
\text { procaine }\end{array}$ & 0.6 & 65 & 56 & 5 & 8.9 \\
\hline
\end{tabular}

From the data of Moore and others (1963); Schroeter and others (1971)

This Table shows not only that single injections of smaller doses of benzathine penicillin than are in fact used are effective, but also that 2.4 to 4.8 m.u. aqueous procaine penicillin, such as is given in the treatment of gonorrhoea, will be successful in preventing syphilis when exposure to both diseases has occurred simultaneously.

This is not surprising, as complete success with single injections of benzathine penicillin was earlier reported in established seronegative primary syphilis (in which many more organisms are present than in the incubation period) in patients subsequently observed for 2 years (Smith, Kamp, Olansky, and Price, 1956).

Opponents of the procedure, who state that it breeds anxiety in those so treated, base this objection on the belief that information regarding its effectiveness is incomplete and that treated patients should be followed for 2 years (King and Nicol, 1969). Those that offer it, however, usually require today that those treated should be followed only for the same length of time as untreated contacts (i.e. for 3 months) as the evidence suggests that this is sufficient time for the uncured disease to become apparent. Moreover, in these circumstances, it is common experience that as much or more anxiety is expressed by untreated patients than by those who are offered treatment.

There is also an abundance of data concerning patients with gonorrhoea, amongst whom there are some who have also been unknowingly exposed to syphilis. Today, in many published series (e.g. Morrison, Cobbold, Foster, Bor, Spitzer, and Willcox, 1968), more than one-half of patients with gonorrhoea have previously been treated for venereal disease in previous years and yet there are no reports of any significant concealed syphilis in these persons. In the days when syphilis was much more common than it is today (double infections in 3 per cent.) no appreciable incidence of masked syphilis was found in discharged service personnel (Bauer, 1949). In a more recent series of 2,992 patients with gonorrhoea at St. Mary's, only two developed evidence of syphilis in the ensuing 90 days (Woodcock, 1971) and no evidence was found of its being masked for 3 to 6 months. If inadequate doses of penicillin or tetracycline antibiotics are given in incubating syphilis, the infection may be expected to be evident within 90 days, although in most patients given penicillin its appearance has been noted in the third month (Moore and others, 1963).

It is noteworthy that opponents of epidemiological treatment for syphilis recommend only a 3- or at the most 6-month follow-up for patients with gonorrhoea who are given doses of penicillin which may be subcurative for incubating syphilis, and no 2-year follow-up is suggested in these circumstances.

\section{Side-effects}

Side-effects from single injections of penicillin amongst patients suffering from venereal disease with no previous history of penicillin sensitivity are very few, being assessed as 0.63 per cent. in the U.S.A. (Rudolph, 1971) and 0.68 per cent. in London (Wilkinson, 1972). Slightly higher rates $(0.82$ per cent.) have been reported in those given epidemiological treatment for syphilis (Rudolph, 1971).

A proportionately greater problem is posed by the larger number (1.4 to 2.0 per cent. in the British and 6.6 per cent. in the American series) in whom there was a previous history of penicillin sensitivity, as treatment with orally administered tetracyclines and erythromycin in such cases is often unsatisfactory for itinerant and unreliable persons, for whom epidemiological treatment is most indicated.

\section{Likelihood of spread if procedure is not used}

This depends on a number of factors apart from risk of infection, particularly on the degree of promiscuity and on the facilities for observation. Obviously, if sexual intercourse is extremely infrequent, there is little likelihood of spread. The high possibility of spread to regular consorts has already been mentioned.

The default rate of the patients concerned is highly relevant. In British venereal disease clinics, patients treated for gonorrhoea or non-gonococcal urethritis are instructed to return for serological tests over a 3-month period, to exclude incubating syphilis. In London the default rates are high. 
In a number of published series from St. Mary's Hospital, London, involving 5,692 patients with gonorrhoea or non-gonococcal urethritis, $15 \cdot 1$ per cent. failed to return for the initial blood test result (Table XII), but to exclude syphilis a 3-month follow-up is required.

TABLE XII Male patients at St. Mary's Hospital, London, not returning for the initial blond test result

\begin{tabular}{|c|c|c|c|c|}
\hline \multirow[b]{2}{*}{ Disease } & \multirow[b]{2}{*}{$\begin{array}{l}\text { No. } \\
\text { treated }\end{array}$} & \multirow[b]{2}{*}{$\begin{array}{l}\text { No. } \\
\text { followed }\end{array}$} & \multicolumn{2}{|c|}{ Failed to return } \\
\hline & & & No. & Per cent. \\
\hline $\begin{array}{l}\text { Gonorrhoea } \\
\text { NGU }\end{array}$ & $\begin{array}{l}3,508 \\
2,184\end{array}$ & $\begin{array}{l}2,953 \\
1,876\end{array}$ & $\begin{array}{l}555 \\
308\end{array}$ & $\begin{array}{l}15 \cdot 8 \\
14 \cdot 1\end{array}$ \\
\hline Total & 5,692 & 4,829 & 863 & $15 \cdot 2$ \\
\hline
\end{tabular}

Table XIII presents data regarding the later follow-up of 1,767 patients. The number followed was 1,495 , indicating an immediate default rate of 15.4 per cent. Of those followed, 392 returned only because they had symptoms of urethritis, due to treatment failure, to re-infection with gonorrhoea, or to non-gonococcal urethritis. There remained 1,103 patients with no symptoms, and the number of these who were followed-up for more than 2 months was abysmally low, a mere $12 \cdot 3$ per cent. (Table XIII). Even some of those that returned without symptoms of urethritis only did so on account of a new risk causing anxiety or because of some other genital lesion (warts, herpes, scabies, etc.), i.e. $87 \cdot 7$ per cent. evaded proper observation for incubating syphilis. Also most of these patients were being treated with antibiotics which were undergoing evaluation and known prospective itinerants had already been excluded. The overall follow-up at 3 months is therefore often substantially less than this (Woodcock, 1971).

TABLE XIII Follow-up obtained of patients with urethritis at St. Mary's Hospital(a), London, who did not develop recurrent symptoms

\begin{tabular}{|c|c|c|c|c|c|}
\hline \multirow{2}{*}{$\begin{array}{l}\text { Duration of } \\
\text { follow-up } \\
\text { (months) }\end{array}$} & \multirow{2}{*}{$\begin{array}{l}\text { No. } \\
\text { originally } \\
\text { treated }\end{array}$} & \multirow{2}{*}{$\begin{array}{l}\text { No. } \\
\text { followed }^{\mathrm{b}}\end{array}$} & \multirow{2}{*}{$\begin{array}{l}\text { Persons } \\
\text { with no } \\
\text { new } \\
\text { symptoms }\end{array}$} & \multicolumn{2}{|c|}{ Followed } \\
\hline & & & & No. & Per cent. \\
\hline $\begin{array}{l}1-2 \\
2-3\end{array}$ & $\begin{array}{l}1,767 \\
1,767\end{array}$ & $\begin{array}{l}1,495 \\
1,495\end{array}$ & $\begin{array}{l}1,103 \\
1,103\end{array}$ & $\begin{array}{l}200 \\
135\end{array}$ & $\begin{array}{l}18 \cdot 1 \\
12 \cdot 3\end{array}$ \\
\hline
\end{tabular}

ata taken from ten recent publications.

b 15.4 per cent. of those treated defaulted immediately.

c Of urethritis only.

\section{CONGENITAL SYPHILIS}

Both prophylactic and epidemiological treatment are universally used without dispute in the prevention of congenital syphilis, the distinction depending on whether the syphilitic mother is treated before or after the fourth month of pregnancy. The epidemiological profile in these circumstances is shown in Table XIV.

TABLE XIV Preventive and epidemiological treatment of congenital syphilis

\begin{tabular}{|c|c|c|}
\hline Factors & Assessment & Figures \\
\hline $\begin{array}{l}\text { High risk } \\
\text { Effective treatment } \\
\text { Side-effects } \\
\text { Facilities for } \\
\text { observation }\end{array}$ & $\begin{array}{l}\text { Yes } \\
\text { Yes } \\
\text { Few } \\
\text { Yes }\end{array}$ & $\begin{array}{l}81.8 \text { per cent. } \\
94.0 \text { per cent. } \\
0.7 \text { in mother }{ }^{\mathrm{b}} \text { c } \\
\text { Up to } 100 \text { per cent. in } \\
\text { maternity and child } \\
\text { health units }\end{array}$ \\
\hline
\end{tabular}

"Ingraham (1951); Guthe (1958).

"Wilkinson (1972).

'Rudolph (1971).

Although the possibility of follow-up can be nearly complete in maternity and child welfare clinics in developed countries, no-one would wait for the establishment of the diagnosis in the child, and virtually all physicians use the treatment either with a deliberate prophylactic intention or under the also valid cloak of treating the mother.

\section{Summary and conclusions}

(1) 'Prophylactic' or 'preventive' treatment is given before exposure to risk of infection with malaria and before cardiac surgery or mid-thigh amputation, and after exposure in cases of upper respiratory infection in chronic bronchitics and asthmatics.

(2) 'Epidemiological' or 'abortive' treatment after exposure is widely used in wound infections, in possible septic abortion, and in prolonged labour. It has also been given on an experimental basis against smallpox.

(3) Epidemiological treatment has been the mainstay of the WHO-assisted mass campaigns against the non-venereal treponematoses, pinta, yaws, and endemic syphilis, in which millions of patients have been involved. Indeed, endemic syphilis was quickly eradicated from Bosnia by its intensive application. (4) The use of epidemiological treatment in venereal syphilis is reviewed. The reported overall risk of infection is between 15 and 30 per cent., being much greater amongst regular consorts, and the treatment is extremely effective with a low incidence of sideeffects. If it is not used, the long delays in diagnosis and the often very high default rates of persons under observation combine to encourage spread of the disease. 
(5) There is little firm evidence to suggest that ineffective doses of antibiotics will delay the appearance of evidence of syphilis beyond the third month, and treated patients may be discharged after the same time period and method of follow-up as those not receiving such treatment. Certainly few physicians today even attempt to follow for more than 3 months patients who have been treated for gonorrhoea with penicillin.

(6) 'Prophylactic' and 'epidemiological' treatment, so defined according to the stage of pregnancy, is universally practised for the prevention of congenital syphilis; if not deliberately given for this purpose, prophylaxis of the disease in the infant is implied in the treatment of the mother.

\section{References}

Alexander, L. J., and Schoch, A. (1949) Arch. Derm. Syph., 59, 1

AMERican Social Health Association (1968) 'Today's VD Problem'. New York

BaUer, D. J. (1967) Paper presented to Vth International Congress of Chemotherapy, Vienna. Abstract, Vol. 2, p. 1227

BAUER, T. J. (1949) f. vener. Dis. Inform., 30, 185

BROWN, W. J. (1971) 'Status and Control of Syphilis in the United States'. Unpublished document

GARNER, M. F. (1968) Med. f. Aust., 1, 672

GJESTLAND, T. (1955) 'The Oslo Study of Untreated Syphilis'. Acta derm.-venereol. (Stockh.), 35, Suppl. 34

GrIN, E. (1953) 'Epidemiology and Control of Endemic Syphilis'. WHO Monograph Ser., Geneva

GutHE, T. (1958) Bull. Wld Hlth Org., 19, No. 3, p. 405

— and IDSøE, O. (1968) Brit. F. vener. Dis., 44, 35

,-- , and Willcox, R. R. (1958) Bull. Wld Hlth Org., 19, 427

- and WILlcox, R. R. (1971) Roy. Soc. Hlth f., 91, 122

INGRAHAM, N. R. (1951) Acta derm.-venereol. (Stockh.), 31, Suppl. 24, p. 60

KING, A. J. (1954) Brit. F. vener. Dis., 30, 13

- (1968) Brit. med. F., 4, 581

- and Nicol, C. S. (1969) 'Venereal Diseases', 2nd ed. Baillière, Tindall and Cassell, London

KIRÁLY, K. (1971) Paper presented to WHO Working Group on the Inter-Country Spread of Venereal Disease, Copenhagen

Marcussen, P. V. (1953) Amer. F. Syph., 37, 355

MOORE, M. B., Price, B. V., Knox, J. N., and ElgiN, L. W. (1963) Pub. Hlth Rep. (Wash.), 78, 966

Morrison, G. D., Cobbold, R. J. C., Bor, S., Spitzer, R. J., FosteR, D. N., and Willcox, R. R. (1968) Brit. F. vener. Dis., 44, 319

Niel, G., and Fribourg-Blanc, A. (1965) Bull. Wld Hlth Org., 33, 89

Norins, L. C. (1968) Brit. F. vener. Dis., 44, 103

O'Grady, F. W. (1972) F. roy. Coll. Physcns (Lond.), 6, 203
Rhodes, F. A., and Anderson, S. E. J. (1970) Papua and New Guinea med. F., 13, 49

Rudolph, A. H. (1971) Paper presented to National VD Conference, Atlanta, Georgia

SCHROETER, A. L., TURNER, R. H., LuCAS, J. B., and Brown, W. J. (1971) f. Amer. med. Ass., 218, 711

Smith, C. A., Kamp, M., Olansky, S., and Price, E. V. (1956) Bull. Wld Hlth Org., 15, 1087

United States Public Health Service (1968) 'Syphilis. A Synopsis'. Publ. No. 1660. Washington, D.C.

VAN DER SLUIS, I. (1969) 'The Treponematosis of Tahiti'. B.N. Israel, Amsterdam

WHO (1953) Expert Committee on Venereal Infections and Treponematoses, Fourth Report. WHO Tech. Rep. Ser., No. 63, Geneva

- (1960) Expert Committee on Venereal Infections and Treponematoses, Fifth Report, WHO Tech. Rep. Ser., No. 190

- (1972a) Press release WHO/14, Geneva

- (1972b) KIRÁLY, K.-personal communication

- (1972c) Report of International Travelling Seminar to the U.S.A., in press

- (1972d) 'Report of Working Group on the InterCountry Spread of Venereal Disease, Copenhagen, 1971'. Regional Office for Europe, WHO, Copenhagen.

Wilkinson, A. E. (1972) f. roy. Coll. Physcns (Lond.), 6, 175

WILlCox, R. R. (1954) Brit. f. vener. Dis., 30, 7

- (1964) 'Textbook of Venereal Diseases and Treponematoses', 2nd ed. Heinemann, London

- (1968) Brit. med. F., 4, 388

Woodcock, K. R. (1971) Brit. F. vener. Dis., 47, 95

\section{Le traitement épidémiologique dans les maladies non vénériennes et dans les maladies tréponémiques}

SOMMAIRE ET CONCLUSIONS

(1) Le traitement 'prophylactique' ou 'préventif' est donné avant que le sujet soit exposé au risque d'infection dans le paludisme, avant un acte de chirurgie cardiaque ou une amputation de cuisse et après une exposition au risque en cas d'infection des voies respiratoires supérieures chez les bronchitiques chroniques ou les asthmatiques.

(2) Le traitement 'épidémiologique' ou 'abortif' est employé largement dans les infections traumatiques, dans un avortement qui peut être septique et dans le travail prolongé. Il a aussi été donné sur des bases expérimentales contre la variole.

(3) Le traitement épidémiologique a été la pierre angulaire des campagnes de masse soutenues par l'OMS contre les tréponématoses non vénériennes-pinta, pian et syphilis endémique-dans lesquelles des millions de sujets ont été impliqués. C'est la vérité que la syphilis endémique fut rapidement éradiquée de Bosnie par l'application intensive du traitement par la pénicilline.

(4) Le traitement épidémiologique dans la syphilis est passé en revue. Selon les rapports disponibles, le risque 
total d'infection se situe entre 15 et 30 pour centlargement au-dessus chez les partenaires réguliers-et le traitement est très efficace avec une faible incidence d'effets secondaires. S'il n'est pas employé, de longs retards dans le diagnostic et l'habituel très haut taux de défection des sujets en observation se combinent pour favoriser l'extension de la maladie.

(5) Il y a peu de preuves formelles suggérant que des doses inefficaces d'antibiotiques retarderaient plus de trois mois l'apparition d'une syphilis évidente, les sujets ainsi traités peuvent ne plus être convoqués après ce délai et la méthode de surveillance est la même que pour ceux qui n'auraient pas reçu un tel traitement. Certainement, il y a peu de médecins actuellement qui essayent même de suivre plus de trois mois les malades qui ont été traités par la pénicilline.

(6) Les traitements 'prophylactique' et 'épidémiologique', ainsi définis selon le stade de la grossesse, sont employés dans la prévention de la syphilis congénitale; bien qu'il ne soit pas donné délibérément dans ce but, le traitement prophylactique de l'enfant est impliqué dans le traitement de la mère. 